\title{
Citation Analysis of the Articles Published in the Bagcilar Medical Bulletin Between December 2016 and June 2020
}

\author{
Bağcılar Tıp Bülteni'nde Aralık 2016 ve Haziran 2020 Tarihleri Arasında \\ Yayımlanan Makalelerin Atıf Analizlerinin Değerlendirilmesi
}

\author{
(D) Aykut Çolakerol, (D Mustafa Zafer Temiz, (D Salih Zeki Sönmez, (Dİbrahim Hacıbey, \\ (D) Ramazan Ömer Yazar, (D) Engin Kadıralı, (D) Atilla Semerciöz
}

University of Health Sciences Turkey, İstanbul Bağcılar Training and Research Hospital, Clinic of Urology, İstanbul, Turkey

\section{Abstract}

Objective: To describe publication characteristic and citation analysis of Bagcilar Medical Bulletin (BMB) since its first publication time to January 2020 using bibliometric methods.

Method: Researched articles published in the BMB between December 2016 and June 2020 have been analyzed. The journal database was evaluated according to study type (original research, review, case report, letter to the editor), related scientific subspecialty and the geographical origin. We also calculated the rates of citation by dividing the total number of citations received by all papers by the total number of papers.

Results: A total of 88 articles were included in the study. The articles about neurosurgery, anesthesia and pediatrics were in the top three $(27.27 \%, 13.63 \%$ and $11.36 \%$, respectively). Citation rates of the original article, case report and review were $15.7 \%, 10.3 \%$ and $0 \%$, respectively. Most of the articles (81.81\%) were published from Marmara Region in Turkey. Of the articles, 4 (4.5\%) were international papers submitted from 2 different countries. All international papers were preclinical subspecialties like pharmacology, microbiology and physiology.

Conclusion: Our study provides an opportunity to compare the citation numbers and characteristics before and after indexing of the journal in TUBITAK/ULAKBIM, in near future.

Keywords: Articles, Bagcilar Medical Bulletin, citation

\section{Öz}

Amaç: Bağcılar Tıp Bülteni (BMB) Dergisi'nin ilk yayın tarihi olan Aralık 2016'dan Haziran 2020'ye kadar olan yayın özelliklerini ve atıf analizini bibliyometrik yöntemler kullanarak tanımlamak.

Yöntem: Aralık 2016-Haziran 2020 yılları arasında BMB'de yayınlanan makaleler analiz edildi. Dergi veritabanı yazıların tipine (orijinal makale, derleme, olgu sunumu, editöre mektup), makalenin ilgili branşına ve coğrafik orijinine göre değerlendirildi. Ayrıca toplam atıf miktarının toplam yayınlanmış makale sayısına bölünmesi suretiyle atıf oranı da hesaplandı.

Bulgular: Toplam 88 makale çalışmaya dahil edildi. Yayınlanan makalelerde ilk 3 sırayı sırasıyla nöroşirurji, anestezi ve reanimasyon ve pediyatri (\%27,27, \%13,6 ve \%11,36) bölümleri aldı. Atıf oranları sırasıyla orijinal makale, olgu sunumu ve derleme olacak şekilde $\% 15,7, \% 10,3$ ve \%0 olarak hesaplandı. Makalelerin birçoğu Türkiye'de Marmara Bölgesi'nden yayınlandı (\%81,81). İki farklı yabancı ülkeden yayınlanan makale sayısı $4(\% 4,5)$ olarak hesaplandı. Bütün yabancı makaleler farmakoloji, mikrobiyoloji ve fizyoloji gibi preklinik branşlara aitti.

Sonuç: Çalışmamız, yakın gelecekte derginin TÜBITAK/ULAKBIM'de indekslenmesinden önceki ve sonraki atıf sayılarını ve özelliklerini karşılaştırma fırsatı sunmaktadır.

Anahtar kelimeler: Atıflar, Bağcılar Tıp Bülteni, makaleler

Address for Correspondence: Aykut Çolakerol, University of Health Sciences Turkey, İstanbul Bağcılar Training and Research Hospital, Clinic of Urology, ìstanbul, Turkey

E-mail: aykutcolakerol@hotmail.com ORCID: orcid.org/0000-0002-5076-5306 Received: 09.02.2021 Accepted: 04.03.2021

Cite this article as: Çolakerol A, Temiz MT, Sönmez SZ, Hacıbey I, Yazar RÖ, Kadıralı E, Semerciöz A. Citation Analysis of the Articles Published in the Bagcilar Medical Bulletin Between December 2016 and June 2020. Bagcilar Med Bull 2021;6(2):157-160

${ }^{\circ}$ Copyright 2021 by the Health Sciences University Turkey, Bagcilar Training and Research Hospital Bagcilar Medical Bulletin published by Galenos Publishing House. 


\section{Introduction}

Bagcilar Medical Bulletin (BMB) is periodical scientific publishing of University of Health Sciences Turkey, Bagcilar Training and Research Hospital. The journal has been published since December issue of 2016 as an e-journal. The journal is published quarterly in March, June, September and December, and it is indexed in EBSCO, Gale, Turk Medline, Turkey Citation Index, Index Copernicus, ProQuest, J-Gate, EuroPub and ScopeMed. However, in Turkey, indexing a journal in TUBITAK/ ULAKBIM scientific database is more important, especially for authors in terms of academic advancements. In this regard, journals indexing in TUBITAK/ULAKBIM are more popular for the authors who attend to submit their works. Starting on June 2020, the journal, BMB, has been indexed in TUBITAK/ULAKBIM and has become a suitable option for medical authors.

In this study, we aimed to describe publication characteristic and citation analysis of $\mathrm{BMB}$ since its first publication time to June 2020, acceptance time of TUBITAK/ULAKBIM database, using bibliometric methods.

\section{Materials and Methods}

Researched articles published in the BMB between December 2016 and June 2020 have been analyzed. Extracted characteristics of published articles were collected from the journal database (http://www. behmedicalbulletin.org/archives.com/eng/archive) according to study type (original research, review, case report, letter to the editor), related scientific subspecialty and the geographical origin. Citation rates were extracted from the Google Scholar citation database (https:// scholar.google.com.tr), which is a meta-database of scholarly journals and books. We also categorized the citations as national and international. Citation rates were calculated by dividing the total number of citations received by all papers by the total number of papers according to article types (such as original research, review, etc.), related scientific subspecialty of articles and intuitional regions of the authors during the period of 2016-2020. Impact factor (IF) could not be determined yet because of the restricted citation numbers of the journal.

\section{Statistical Analysis}

No statistics have been made in this article, so the title of statistics is not included.

\section{Results}

A total of 88 articles were included in the study. The types of the published articles consisted of original articles, review articles and case reports. Details are presented in Table 1. The greater number of the papers were original research articles (64.77\%). Most of the articles (81.81\%) were published from Marmara Region in Turkey. Of the articles, 4 (4.5\%) were international papers submitted from 2 different countries. All international papers were preclinical subspecialties like pharmacology, microbiology and physiology. Among the published articles, articles about neurosurgery, anesthesia and pediatrics were in the top three, respectively $(27.27 \%$, $13.63 \%$ and $11.36 \%$, respectively). The total citation number was established as 12 . International papers had received 6 citations up to June 2020. Overall citation rate was $26 \%$. Citation rates of the original articles and case reports were $15.7 \%$ and $10.3 \%$, respectively. Interestingly review articles had not been cited yet. The top cited articles were about pharmacology and microbiology subspecialties. The detailed information about citation characteristics for article types and subspecialties are shown in Table 1 and 2, respectively.

\section{Discussion}

The term bibliométrie was first used by Paul Otlet in 1934 (1). Bibliometric analysis is used for statistical evaluation of published scientific articles and it is an effective method to measure the influence of publication in the scientific area (2-5). Widely used bibliometric tools are citation analysis and IF in the evaluation of research performance (6). The IF of an academic journal is a scientometric index that reflects the yearly average number of citations that articles published in the last two years in a given journal have received $(7,8)$. It is reported by Foster that there is a correlation between IF and journal prestige (9). Tsay has underlined that IF is a significant measure of importance that could be used for journal selection (10).

There are many factors that can affect the citation characteristics of a publication. In the medical sciences,

Table 1. The types of the articles published in the BMB

\begin{tabular}{llll} 
Article type & $\begin{array}{l}\text { Citation } \\
\text { count }\end{array}$ & $\begin{array}{l}\text { Article } \\
\text { count }\end{array}$ & $\begin{array}{l}\text { Citation } \\
\text { rate }\end{array}$ \\
\hline Original research article & 9 & 57 & 0.157 \\
Review & 0 & 2 & 0 \\
Case report & 3 & 29 & 0.103 \\
Total & 12 & 88 & 0.260
\end{tabular}

BMB: Bagcilar Medical Bulletin 
previous studies have for instance analyzed the effect of study design (e.g., case report, randomized controlled trial, or meta-analysis), article type (i.e., brief report or full-size article), and article length (6). In our study, we investigated the differences in article type, region and subspecialty of article for citation characteristics.

BMB is periodical scientific publishing of University of Health Sciences Turkey, Bagcilar Training and Research Hospital since December 2016 and it is indexed in TUBITAK/ULAKBIM since June 2020. In the present study, we performed a comprehensive evaluation of the articles published in the BMB and we calculated the number of citations before being indexed in TUBITAK/ ULAKBIM. We found that articles published in the field of pharmacology and microbiology had higher citation rates compared to other subspecialties. The most published three articles were about neurosurgery $(n=24)$, anesthesia $(n=12)$ and pediatric $(n=10)$ but there were only 3 citations with these 46 articles and all of them were cited in neurosurgery. We think that relatively young nature of the journal and poor indexing characteristics might have played a role as a reason of it. Most cited articles were in preclinical subspecialties and submitted from foreign

Table 2. Citation counts according to the subspecialties

\begin{tabular}{lll} 
Article type & $\begin{array}{l}\text { Citation } \\
\text { count }\end{array}$ & $\begin{array}{l}\text { Article } \\
\text { count }\end{array}$ \\
\hline Neurosurgery & 3 & 24 \\
Anesthesia & 0 & 12 \\
Pediatrics & 0 & 10 \\
Cardiovascular surgery & 1 & 4 \\
Orthopedics & 1 & 2 \\
Urology & 0 & 3 \\
Emergency & 0 & 6 \\
General surgery & 1 & 3 \\
Otolaryngology/head and neck surgery & 0 & 4 \\
Gynecology and obstetrics & 0 & 4 \\
Aesthetic and plastic surgery & 0 & 2 \\
Internal medicine & 0 & 3 \\
Cardiology & 0 & 1 \\
Physical therapy and rehabilitation & 0 & 1 \\
Nuclear medicine & 0 & 1 \\
Neurology & 0 & 1 \\
Pharmacology & 0 & 2 \\
Microbiology & 0 & 2 \\
Physiology & 0 & 1 \\
Radiology & 0 & 1 \\
Total & 0 & 2 \\
\hline & 0 & 1 \\
\hline & 0 & 2 \\
\hline
\end{tabular}

countries. These data demonstrate that more published international papers provide more citation numbers and high IF.

\section{Study Limitations}

Our study has some limitations. The major one is the lack of the determination of the IF. However, this was not suitable for the limited number of citations. In future, with the increase in published articles, further studies may help in reduction of this issue. The second limitation is that we could not perform any comparison on citation characteristics. Similarly, as mentioned above, further studies can compare the citation characteristics with increased published articles after indexing in TUBITAK/ ULAKBIM database.

\section{Conclusion}

We think that joining the TUBITAK/ULAKBIM will increase the bibliometric characteristics of the journal. Our study provides an opportunity to compare the citation numbers and characteristics before and after indexing of the journal in TUBITAK/ULAKBIM, in near future.

\section{Ethics}

Ethics Committee Approval: Since this article is a bibliography article that evaluates the properties of articles until June 2020 in Bagcilar Medical Journal, no patient data were used. Therefore, ethical consent and patient consent were not required.

Informed Consent: Since this article is a bibliography article that evaluates the properties of articles until June 2020 in Bagcilar Medical Journal, no patient data were used. Therefore, ethical consent and patient consent were not required.

Peer-review: Internally peer-reviewed.

\section{Authorship Contributions}

Concept: M.Z.T., A.S., E.K., A.Ç., Design: M.Z.T., A.S., E.K., Data Collection or Processing: İ.H., S.Z.S., R.Ö.Y., Literature Search: İ.H., S.Z.S., R.Ö.Y., Analysis or Interpretation: İ.H., S.Z.S., R.Ö.Y., Writing: A.Ç., E.K., M.Z.T., Manuscript Review and Revisation: A.Ç., E.K., A.S.

Conflict of Interest: No conflict of interest was declared by the authors.

Financial Disclosure: The authors declared that this study has received no financial support. 


\section{References}

1. Otlet P. Traité de documentation: le livre sur le livre, théorie et pratique. Mons, Belgium: Editiones Mundaneum; 1934

2. Diagnostic criteria and classification of hyperglycaemia first detected in pregnancy: A World Health Organization guideline. Diabetes Res Clin Pract 2014;103(3):341-363.

3. Metzger BE, Coustan DR. Proceedings of the fourth international work-shop-conference on gestational diabetes mellitus Diabetes Care 1998;(Suppl 2):B161-B167.

4. Schubert A, Glänzel W, Braun T. Scientometrics A comprehensive set of indicators on 2649 journals and 96 countries in all major science fields and subfields 1981-1985. 1989;16:3-478.

5. de Moya AF, Chinchilla RZ, Vargas QB, Corera ÁE, Muñoz FF, Gonzalez MA. Coverage analysis of Scopus: a journal metric approach. Scientometrics 2007;73:53-78.
6. van Eck NJ, Waltman L, van Raan AF, Klautz RJM, Peul WC. Citation analysis may severely underestimate the impact of clinical research as compared to basic research. PLoS One 2013;8(4):e62395. doi: 10.1371/journal.pone.0062395.

7. Garfield, E. Journal impact factor: a brief review. CMAJ 1999;161(8):979-980.

8. Glänzel W, Moed HF. Journal impact measures in bibliometric research. Scientometrics 2002;53(2):171193. doi:10.1023/A:1014848323806.

9. Foster WR. Impact factor as the best operational measure of medical journals. Lancet 1999; 346(8985):1301.

10. Tsay MY. The relationship between journal use in a medical library and citation use. Bull Med Libr Assoc 1998;86(1):31-39. 